UDC 693.546

\title{
USE MODED BAR OF VARIABLE CROSS SECTION IN VIBRATION ANALYSIS OF TELESCOPIC BOOM SYSTEM OF TRUCK-MOUNTED CRANES
}

\author{
I. M. Sivak, Yu. V. Chovnyuk
}

National University of Life and Environmental Sciences of Ukraine. Ukraine

Speciality of article: 133 - industry engineering.

Corresponding authors: ychovnyuk@ukr.net

Article history: Received - October 2019, Accepted - January 2020.

Bibl. 13, fig. 3, tabl. 0 .

Abstract. The discrete-continual model of the rod of variable section for the analysis of oscillations of telescopic rotor systems of cranes is substantiated.

As methods for solving the basic equations (for bending type oscillations), the methods of Ritz and Budnov-Galerkin using the Relay formula are used to calculate the proper frequency of oscillations of the considered system using a model with lumped parameters (discrete models) and taking into account the distributed properties of the systems being studied.

The approaches used for the thorough analysis of the continual (distributed) properties of telescopic boom systems of mobile cranes and the analysis of variations of oscillations (longitudinal, twisting and bent) of telescopic boom systems of autocranes taking into account the circumstances of mass distribution along the arrow (rod) with a variable section of the rod along its length.

Approximate methods of analysis and improvement of methods for calculating various types of oscillations that arise in the rods of a variable section are presented, within the framework of consideration of telescopic boom systems of cranes as having discrete - continual properties.

Equations are constructed using the BubnovGalerkin method in the problems of longitudinal or steep oscillations of telescopic rotor systems of cranes.

Key words: model, rod, variable section, analysis, oscillations, telescopic boom system, truck cranes.

\section{Introduction}

To analyze the kinds of oscillations (longitudinal, twisting and bending) telescopic boom cranes systems should take into account the fact that the weight is distributed along the arrows (core) and core section is variable along its length.

In this case, instead of, for example, the classical equation of longitudinal vibrations (when constant-section rod) must come from one of the following equations:

$$
c^{2} \cdot \frac{\partial}{\partial x}\left(S \cdot \frac{\partial u}{\partial x}\right)=S \cdot\left(\frac{\partial^{2} u}{\partial t^{2}}\right),
$$

where: c - velocity of longitudinal vibrations propagating in the core, $\mathrm{S}$ - area of its cross section $S=S(x)$ $u=u(x, t)-$ Longitudinal movement of arbitrary crosssection of the rod, $\mathrm{x}$ - longitudinal coordinate (along the core axis), $\mathrm{t}$ - time.

Equation core twisting oscillations should be considered as:

$$
c_{1}^{2} \cdot \frac{\partial}{\partial x}\left(I \cdot \frac{\partial \varphi}{\partial x}\right)=I \cdot \frac{\partial^{2} \varphi}{\partial t^{2}},
$$

where: $c_{1}-$ speed twisting waves propagating in the core, I - polar moment of inertia of the rod, $I=I(x), \varphi=\varphi(x, t)$ - angle cross-section of the rod relative to its axis ( $\mathrm{x}$ in any section of the rod).

Equation transverse (bending) oscillations of the rod should be seen in the following form:

$$
\frac{\partial^{2}}{\partial x^{2}}\left(E I \cdot \frac{\partial^{2} y}{\partial x^{2}}\right)=-m \frac{\partial^{2} y}{\partial t^{2}},
$$

where: EI - bending stiffness of the rod, EI = EI (x), m weight rod, $y(x, t)$ - arbitrary displacement rod section $(\mathrm{x})$ in the direction perpendicular to its axis.

It should be noted that the equations (1)-(3) using similar substitutions could lead to ordinary differential equations for the function $\mathrm{X}(\mathrm{x})$ :

$$
\begin{gathered}
\left(S \cdot X^{\prime}\right)^{\prime}+\frac{p^{2}}{c^{2}} \cdot S \cdot X=0 ;\left(I \cdot X^{\prime}\right)^{\prime}+\frac{p^{2}}{c_{1}^{2}} \cdot I \cdot X=0 ; \\
\left(E \cdot I \cdot X^{\prime \prime}\right)^{\prime \prime}-m p^{2} \cdot X=0,
\end{gathered}
$$

bar near where function means differentiation with respect to spatial coordinates $\mathrm{x}$, and the other equation for the function $\mathrm{T}(\mathrm{t})$.

\section{Formulation of problem}

Basic models of telescopic boom cranes investigated in [1-21]. However, the authors of these works use models with lumped parameters (ie discrete model) and do not include distributed properties of the systems. The 
authors of this study, it is advisable to use approaches developed in [8] for a comprehensive analysis is continual (distributed) properties telescopic jib cranes systems.

\section{Analysis of recent research results}

Issued above equation (1) - (4) are variable factors dependent on $\mathrm{x}$. Solution in closed form is available only in certain cases where the variable $\mathrm{S}(\mathrm{x}), \mathrm{I}(\mathrm{x}), \mathrm{J}(\mathrm{x})$ by special dependency and, in general, is the transition to approximate methods (where $\mathrm{J}(\mathrm{x})$ - point inertia in the core section $\mathrm{x}$, and $\mathrm{E}$ - in the above (3) is elastic modulus (Young's) core material). Some of these approximate methods are set forth below in connection with the need to analyze and improve methods for calculating the different types of vibrations that occur in the core variable section within review telescopic jib cranes as such systems with discrete - continuum properties.

\section{Purpose of research}

The purpose of the work is the justification of approximate methods for the analysis of different kinds of vibrations arising in telescopic boom cranes systems that take into account their discrete - continuum properties.

To achieve these objectives in this study will be part on the work [8].

\section{Results of research}

Below are justified and some methods of approximate solutions of bending vibration rods constant and variable section that allow variables to investigate fluctuations telescopic jib cranes systems.

1. Vereshchagin method (for permanent core section). Composition and solve the differential equation of free oscillations console (model telescopic boom cranes system that is in operation (the unfolded throughout dovzhnynu state). We use the approach of [9]. We believe that the ends (free) console is a load, which has finite moment of inertia (Fig. 1 a), in addition, neglect beam weight compared to the weight of cargo. Fig. 1 introduced the following notation: 1 - the length of the console, EI - its bending stiffness, $\mathrm{m}$ - weight cargo, $\mathrm{g}-$ its radius of inertia.

The proposed system has two degrees of freedom of movement, and generalized coordinates for convenient and appropriate to choose a console deflection and rotation angle $\varphi$ end console (Figure 1b).

For the purposes of differential equations of motion and use the reverse method, consider bending lagless skeleton, which is shown in Fig. 1.

External forces are inertia load $-\mathrm{m} \cdot \mathrm{Q} 2 \cdot$ then: $\ddot{\varphi}$

$$
\begin{aligned}
& y=\cdot \delta 11-m \rho 2 \cdot \varphi=-m \cdot \delta 12-m \rho 2 \cdot \cdot-\ddot{m} \cdot y \ddot{\varphi} \cdot \\
& \delta_{12} \ddot{y} \ddot{\varphi} \delta_{22}
\end{aligned}
$$

This point was over a function of mean differentiation over time t.

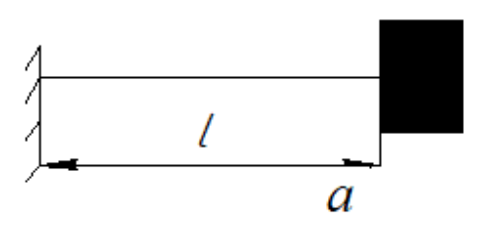

m. $\mathrm{g}$
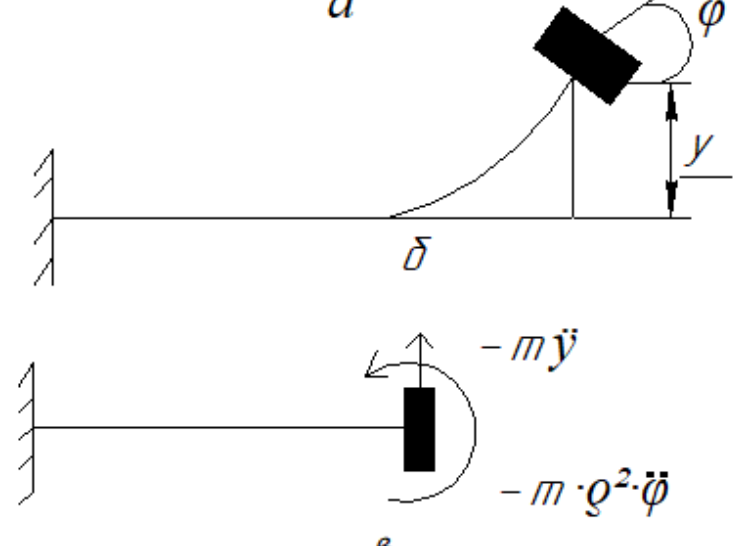

$B$

Fig. 1. Diagram console by Vereshchagin

Factors influence $\delta 11, \delta 12, \delta 21, \delta 22$ available methods of strength of materials, for example, using the formula Vereshchagin. In this case, they are expressed as follows:

$$
\delta_{11}=\frac{l^{3}}{3 E I}, \delta_{12}=\frac{l^{2}}{2 E I}, \delta_{22}=\frac{l}{E I} .
$$

Thus the differential equations of motion take the form:

$$
\left\{\begin{array}{l}
m \cdot \ddot{y} \cdot \frac{l^{3}}{3 E I}+m \varrho^{2} \cdot \ddot{\varphi} \cdot \frac{l^{2}}{2 E I}+y=0 ; \\
m \cdot \ddot{y} \cdot \frac{l^{2}}{2 E I}+m \rho^{2} \cdot \ddot{\varphi} \cdot \frac{l}{E I}+\varphi=0 ;
\end{array}\right\}
$$

Partial solution (7) provided (stability criterion) Sylvester equilibrium for the considered system (consider this criterion is met) can be written as:

$$
q_{j}=\cdot \sin (k t+\alpha), j=(1,2) \cdot A_{j}
$$

These expressions described monoharmonic oscillatory mode with frequency $\mathrm{k}$, the total for all coordinates (ie y and $\varphi$ ). (Note that when the Sylvester criterion system which is derived from the equilibrium, provides free oscillations) $q_{j}$.

Substituting (8) in the differential equation (7), we obtain a homogeneous system:

$$
\left\{\begin{array}{c}
\left(\frac{m l^{3}}{3 E I} \cdot k^{2}-1\right) \cdot m \mathrm{~g}^{2} \cdot \frac{l^{2}}{2 E I} \cdot k^{2} \cdot A_{2}=0 ; \\
\frac{m l^{2}}{2 E I} \cdot k^{2} \cdot A_{1}+\left(\frac{m \mathrm{~g}^{2} \cdot l}{E I} \cdot k^{2}-1\right) \cdot A_{2}=0 .
\end{array}\right\}
$$

Equating to zero the determinant of the system (9), we obtain the following frequency equation:

$$
\frac{m^{2} \mathrm{~g}^{2} l^{4}}{12 \cdot(E I)^{2}} \cdot k^{4}-\left(\frac{m \mathrm{~g}^{2} l}{E I}+\frac{m l^{3}}{3 E I}\right) \cdot k^{2}+1=0 .
$$

Its roots have the following form:

$$
\begin{gathered}
k_{1,2}^{2}=\frac{1}{2} \cdot \frac{\left(\frac{m_{g}^{2} l}{E I}+\frac{m l^{3}}{3 E I}\right)}{\left[\frac{m^{2} g^{2} l^{4}}{12 \cdot(E I)^{2}}\right]} \pm\left\{\frac{1}{4} \cdot \frac{\left(\frac{m_{g}^{2} l}{E I}+\frac{m l^{3}}{3 E I}\right)^{2}}{\left[\frac{m^{2} g^{2} l^{4}}{12 \cdot(E I)^{2}}\right]^{2}}-\right. \\
\left.\left[\frac{m^{2} \rho^{2} l^{4}}{12 \cdot(E I)^{2}}\right]^{-1}\right\}^{\frac{1}{2}}
\end{gathered}
$$

$\mathrm{g}<<1$ have from (11):

$$
k_{1}^{2} \approx \frac{3 E I}{m l^{3}}\left(1-\frac{q \mathrm{~g}^{2}}{4 l^{2}}\right) ; k_{2}^{2} \approx \frac{q E I}{m l^{3}} \cdot\left(1+\frac{u l^{2}}{q \mathrm{~g}^{2}}\right) \text {. }
$$


To find their own forms of oscillations of the system will create relationship (A1 / A2) from the first equation of (9):

$$
\frac{A_{1}}{A_{2}}=\frac{\left(1-\frac{m l^{3}}{3 E I} \cdot k^{2}\right)}{\left(m \mathrm{\rho}^{2} \cdot \frac{l^{2}}{2 E I} \cdot k^{2}\right)} .
$$

Substituting here each of the found values and higher (by formulas (11) or (12) $k_{1}^{2} k_{2}^{2}$ have:

$$
x_{21}=\approx ; \approx-\frac{A_{21}}{A_{11}} \frac{3}{2 l} x_{22}=\frac{A_{22}}{A 12} \frac{2 l}{3 \mathrm{~g}^{2}} \text {. }
$$

These value (14) characterizing their two farms (Fig. 2, b).

As shown in Figure 2, the first own farm has a relatively low load angle and the second form - relatively small deflection end of the console.

Find the data traffic law system if its equilibrium is disturbed is applied to the center of gravity of the cargo instant momentum $\tilde{s}$.
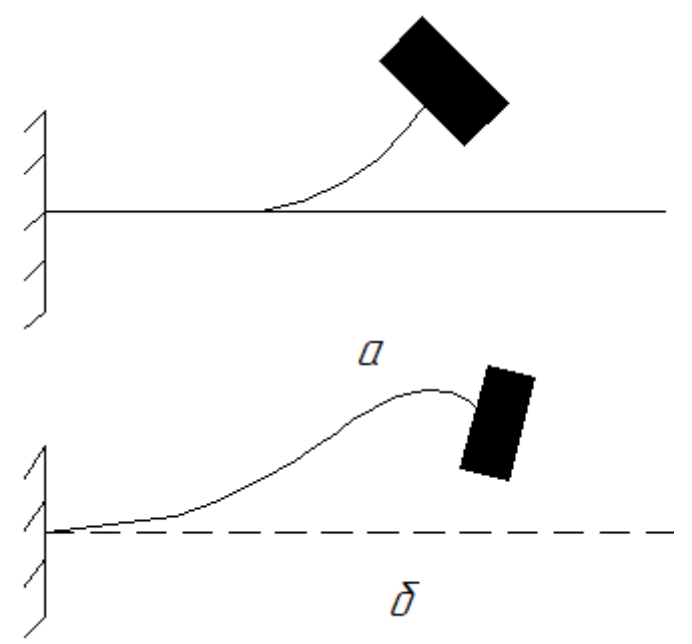

Fig. 2. Proper form fluctuations Console

In this case, the initial conditions must be formulated as follows:

$$
y(0)=0,(0)=, \varphi(0)=0=0 . \dot{y} \frac{\tilde{s}}{m} \dot{\varphi} .
$$

General solution now looks like: $\left\{\begin{array}{l}y=A_{11} \cdot \sin \left(k_{1} \cdot t+\alpha_{1}\right)+A_{12} \cdot \sin \left(k_{2} t+\alpha_{2}\right) \\ \varphi=A_{21} \cdot \sin \left(k_{1} t+\alpha_{1}\right)+A_{22} \cdot \sin \left(k_{2} t+\alpha_{2}\right)\end{array}\right\}(16)$

Substituting here from (16) found the ratio of amplitudes (14), we find:

$$
\left\{\begin{array}{c}
y=A_{11} \cdot \sin \left(k_{1} t+\alpha_{1}\right)+ \\
+A_{12} \cdot \sin \left(k_{2} t+\alpha_{2}\right), \\
\varphi=\frac{3}{2 l} \cdot A_{11} \cdot \sin \left(k_{1} t+\alpha_{1}\right)- \\
-\frac{2 l}{3 g^{2}} \cdot A_{12} \cdot \sin \left(k_{2} t+\alpha_{2}\right) .
\end{array}\right\}
$$

To determine the four unknowns use the above initial conditions (15) $A_{11}, A_{12}, \alpha_{1}, \alpha_{2}$ :

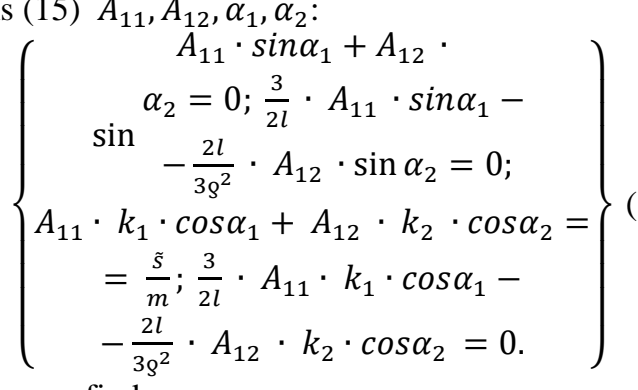

Hence we find:

$$
A_{11}=\frac{\tilde{s} \cdot l^{2}}{\sqrt{3 m l E I}}, A_{12}=\frac{q \tilde{s} \cdot \rho^{2}}{8 l \cdot \sqrt{m l E I}}, \alpha_{1}=0 ; \alpha_{2}=0 \text {. (19) }
$$

Accordingly, the motion is described by the equations:

$$
\left\{\begin{array}{l}
y(t)=\frac{\tilde{s} \cdot l^{2}}{\sqrt{m l E I}} \cdot\left[\frac{1}{\sqrt{3}} \cdot \sin k_{1} t+\frac{9}{8} \cdot \frac{\rho^{3}}{l^{3}} \cdot \sin k_{2} t\right] ; \\
\varphi(t)=\frac{\tilde{s} \cdot l}{\sqrt{m l E l}} \cdot\left[\frac{\sqrt{3}}{2} \cdot \sin k_{1} t-\frac{3}{4} \cdot \frac{9}{l} \cdot \sin k_{2} t\right] .
\end{array}\right\}
$$

2. Ritz method.

Wonder several functions, $(\mathrm{x}), \ldots,(\mathrm{x})$, each of which meets the geometric boundary conditions of the problem and form function $\mathrm{f}(\mathrm{x}) f_{1}(x) f_{2} f_{n}$ as the sum of:

$$
f(x)=\ldots+\cdot \overline{c_{1}} \cdot f_{1}+\overline{c_{2}} \cdot f_{2}+\overline{c_{n}} f_{n}
$$

Substituting the function (21) in Rayleigh formula:

$$
p^{2}=\frac{\int_{0}^{l} E I \cdot\left(f^{\prime \prime}\right)^{2} d x}{\left[\int_{0}^{l} m f^{2} d x\right]},
$$

then the result will depend on the particular choice of ratios $\overline{c_{1}}, \overline{c_{2}}, \ldots, \overline{c_{n}}$.

Ritz method allows the use of a simple idea: coefficients $\overline{c_{1}}, \overline{c_{2}}, \ldots, \overline{c_{n}}$.

Must be chosen so that the calculation formula (22) would give the least importance to. Theorem Rayleigh follows that such a choice would be the best (if this system function) $p^{2} f_{i}$.

Minimum conditions have the form $p^{2}$ :

$$
\frac{\partial}{c_{i}}\left[\frac{\int_{0}^{1} E I \cdot\left(f^{\prime \prime}\right)^{2} d x}{\int_{0}^{1} m f^{2} d x}\right]=0(i=1,2, \ldots, n),
$$

ie:

$$
\begin{gathered}
{\left[\frac{\partial}{\partial \bar{c}_{1}} \int_{0}^{l} \mathrm{EI}\left(\mathrm{f}^{\prime \prime}\right)^{2} \mathrm{dx}\right] \cdot\left[\int_{0}^{l} m f^{2} d x\right]-\left[\frac{\partial}{\partial \bar{c}_{l}} \int_{0}^{l} m f^{2} d x\right] \cdot} \\
{\left[\int_{0}^{l} E I \cdot\left(f^{\prime \prime}\right)^{2} d x\right] .}
\end{gathered}
$$

Divide equation (24) integral to and including the formula (22) $\int_{0}^{l} m f^{2} d x$ have:

$$
\frac{\partial}{\partial \bar{c}_{l}} \int_{0}^{l}\left[E I \cdot\left(f^{\prime \prime}\right)^{2}-p^{2} \cdot m f^{2}\right] d x=0, i=1,2, \ldots, n .
$$

Equation (25) is relatively homogeneous and linear, ..., and their number is equal to the number of members of the expression (21). Equating to zero the determinant composed of coefficients at, ..., will have a frequency equation. This equation not only gives a good approximation for naymenschoyi frequency, but also identifies (but less accurate) value higher frequencies. It can be found as much frequency as components made in expression (21) $\overline{\mathrm{c}_{1}} \overline{\mathrm{C}_{2}} \overline{\mathrm{c}_{1}} \overline{\mathrm{c}_{2}}$.

Ritz method as Rayleigh method allows to solve the problem in the case of discontinuous functions and EI $\mathrm{m}$, when these functions are different analytical expressions for different parts of the beam length / console.

Define by Ritz lowest natural frequency of transverse vibrations console variable section, which has a thickness equal to the conventional one.

Height varies linearly (Fig. 3):

$$
h_{x}=x \cdot \mathrm{I}=\frac{\mathrm{h}}{\mathrm{l}} h^{3} \cdot \frac{x^{3}}{\left(12 l^{3}\right)} ; m=\mathrm{\rho} h \cdot \frac{x}{l} \text {. }
$$

For the approach of looking for solution of using:

$$
f(x)=\overline{c_{1}} \cdot\left(1-\frac{x}{l}\right)^{2}+\overline{c_{2}} \cdot x \cdot \frac{\left(1-\frac{x}{l}\right)^{2}}{l} \text {. }
$$

Each member of this example satisfies the boundary conditions of the problem:

$$
f_{1}=0, f_{2}=0, f_{1}^{\prime}=0, f_{2}^{\prime}=0, x=0 .(28)
$$

If limited to one member, then get Rayleigh method (error of about $3 \%$ ): 


$$
p=1,582 h \cdot \frac{\sqrt{\frac{E}{\rho}}}{l^{2}} .
$$

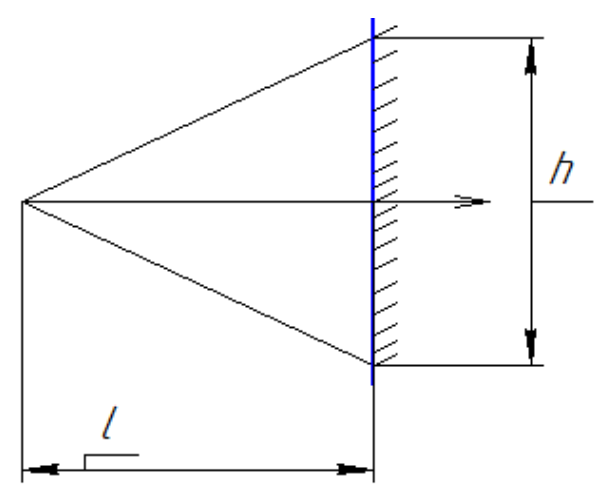

Fig. 3. Diagram console (26)

To get a better approximation, we take two terms of the expansion. Substituting them into expression (25), then we will have integral values:

$$
\begin{gathered}
h^{3} \cdot \frac{\left[\left(\overline{c_{1}}-2 \overline{c_{2}}\right)^{2}+24 \cdot \overline{c_{2}} \cdot \frac{\left(\overline{c_{1}}-2 \overline{c_{2}}\right)}{5}+6 \cdot \bar{c}_{2}^{2}\right]}{\left(12 l^{3}\right)}-p^{2} \cdot \mathrm{g} h l \cdot \neq+ \\
\text { O. } \frac{\left(\frac{\overline{c_{1}^{2}}}{30}+\frac{2 \overline{c_{1} c_{2}}}{105}+\frac{\overline{c_{2}^{2}}}{280}\right)}{E}
\end{gathered}
$$

Differentiating the expression (30) on the first then on, we will have: $\bar{c}_{1}, \bar{c}_{2}$

$$
\left\{\begin{array}{l}
{\left[\frac{E^{2}}{\left(12 \mathrm{gl}^{4}\right)}-\frac{\mathrm{p}^{2}}{30}\right] \cdot \overline{\mathrm{C}_{1}}+\left[\frac{E \mathrm{E}^{2}}{\left(20 \mathrm{gl}^{4}\right)}-\frac{\mathrm{p}^{2}}{105}\right] \cdot \overline{\mathrm{c}_{2}}=0,} \\
{\left[\frac{E \mathrm{E}^{2}}{\left(12 \mathrm{~g} \mathrm{l}^{4}\right)}-\frac{\mathrm{p}^{2}}{105}\right] \cdot \overline{\mathrm{c}_{1}}+\left[\frac{E \mathrm{~h}^{2}}{\left(20 \mathrm{~g} \mathrm{l}^{4}\right)}-\frac{\mathrm{p}^{2}}{280}\right] \cdot \overline{\mathrm{C}_{2}}=0 .}
\end{array}\right\}
$$

Equating to zero the determinant composed of coefficients of these equations (31), we obtain the equation frequency. Its roots:

$$
p_{1}=1,536 h \cdot ; \frac{\sqrt{\frac{E}{g}}}{l^{2}} p_{2}=4,994 h \cdot \frac{\sqrt{\frac{E}{9}}}{l^{2}} \text {. }
$$

Find the exact value differs by only $0,1 \% p_{1}$.

3. Bubnov - Galerkin.

In the simplest version of the method according to equation (3) should be in place $\mathrm{X}$ (x) approximately expose selected expression $\mathrm{f}(\mathrm{x})$, which has one uncertain parameter and then form the equation:

$$
\int_{0}^{l}\left[(E \cdot I \cdot f)-m p^{2} \cdot f\right] f d x=0 .
$$

This equation expresses the vanishing of a possible work being done by force of elasticity and inertia of moving $\mathrm{f}(\mathrm{x})$.

If we take $\mathrm{f}(\mathrm{x})$ as (21) and examine each of the components (x), as a possible move then instead of (33) will have a ratio that expresses the vanishing of the possible: $f_{i}$

$$
\int_{0}^{l}\left[\left(E I \cdot f^{\prime \prime}\right) "-m p^{2} \cdot f\right] \cdot f_{i} \cdot d x=0, i=1,2 .
$$

Such equations can be written as many constituents have adopted the expression (21). Each of equations (34) and has a uniform uncertain size, ... in the first degree $\overline{\mathrm{c}_{1}} \overline{\mathrm{c}_{2}}$.

Equating to zero the determinant of the system (34), will have a frequency equation.

Bubnov-Galerkin has one feature, which refers to the boundary conditions. If the function (x) satisfy only geometric boundary conditions (as stated above, the following functions can be used in solving the problem Ritz method), then it can lead to significant errors in applying the Bubnov-Galerkin. If the selection of features not consider power boundary conditions (for example, to ignore the conditions and at the free end beams / console or on the rocker bearing condition), then it will implicitly acknowledged the existence of the ends of the beam boundary conditions, which in reality is not. This occurs $f_{i} f_{i}(x) f_{i}^{\prime \prime}=0 f_{i}^{\prime \prime \prime}=0 f_{i}^{\prime \prime}=0$.

Error because the expression (34) will come nonexistent work effort. To compensate for the errors should subtract the left side of the expression (34) "extra" work of boundary conditions (collectively BubnovGalerkin). Usually do another take over functions previously not only geometric, but also force boundary conditions. With this feature by selecting Ritz and Galerkin give the same results.

Define Bubnov-Galerkin lowest incidence of transverse vibrations console discussed above in the preceding paragraph.

Accepted forms as fluctuations Console expression:

$$
f(x)=\overline{c_{1}} \cdot\left(1-\frac{x}{l}\right)^{2}+\overline{c_{2}} \cdot x \cdot \frac{\left(1-\frac{x}{l}\right)}{l},
$$

Satisfies a geometric conditions at the right end, and so force conditions on the left.

Differentiating $\mathrm{f}(\mathrm{x})$ twice, multiply by $\mathrm{EI}=\mathrm{E}$. differentiating twice and again, we will have $h^{3} \frac{x^{3}}{\left(12 l^{3}\right)}$ :

$$
\left(E I \cdot f^{\prime \prime}\right)^{\prime \prime}=E \cdot h^{3} \frac{\left[\left(\overline{c_{1}}-2 \overline{c_{2}}\right) \cdot x+6 \overline{c_{2}} \cdot \frac{x^{2}}{l}\right]}{l^{5}}
$$

Substituting this formula in (34), we find:

$$
\int_{0}^{l}\left\{\frac{E h^{3}}{l^{5}} \cdot\left[\left(\overline{c_{1}}-2 \overline{c_{2}}\right) \cdot x+\frac{6 \overline{c_{2}} \cdot x^{2}}{l}\right]-\frac{\rho h p^{2}}{l} \cdot\left[\overline{c_{1}} \cdot x .\right.\right.
$$$$
\left.\left.\left(1-\left(\frac{x}{l}\right)^{2}\right)+\overline{c_{2}} \cdot \frac{x}{l} \cdot\left(1-\frac{x}{l}\right)^{2}\right]\right\} \cdot\left(1-\frac{x}{l}\right)^{2} d x==0 \text {, }
$$

$\int_{0}^{l}\left\{\frac{E h^{3}}{l^{5}}\left[\left(\overline{c_{1}}-2 \overline{c_{2}}\right) \cdot x+\frac{6 \overline{c_{2}} x^{2}}{l}\right]-\frac{\rho h p^{2}}{l} \cdot\left[\overline{c_{1}} \cdot x \cdot\left(1-\frac{x}{l}\right)^{2}+\right.\right.$

$\left.\left.+\overline{c_{2}} \cdot \frac{x}{l} \cdot\left(1-\frac{x}{l}\right)^{2}\right]\right\} \cdot \frac{x}{l}\left(1-\frac{x}{l}\right)^{2} d x=0$.

Hence, too, will have the same equations as in the previous example using Ritz method.

Similarly consist equation method Bubnov-Galerkin in problems of torque fluctuations or longitudinal telescopic jib cranes systems.

\section{Conclusions}

1. A model of the core variable section to analyze different types:

- fluctuations (longitudinal bending, twisting) telescopic jib cranes of analytical methods (Rayleigh Vereshchagin, Ritz, Bubnov - Galerkin) that can determine the natural frequencies of said oscillation,

- and their spatial form (vibrations) that implement such own free fluctuation system.

2. Obtained in the results can be used to further refine and improve existing engineering calculation methods:

- different types of vibrations telescopic jib cranes analytical methods both at the stage of their design / construction,

- and in the mode of real operation using discretecontinuum model core variable section. 


\section{References}

1.Lovejkin, V. S. \& Pochka, K. I. (2004). The dynamic analysis of roller forming installation with the rekuperativ drive. Dynamics, durability and reliability of farm vehicles. Works of the first International scientific and technical conference (DSR AM-I), 507-514. Ternopil.

2.Lovejkin, V. S. \& Pochka, K. I. (2007). Results of pilot studies of the modes of the movement of roller forming installation with the rekuperativ drive. The bulletin of the Kharkov national university of agriculture of P. Vasilenko, vol. 1, No. 59, 465-474.

3.Nazarenko, I. I., Smirnov, V. M., Pelevin, L. C., Fomin, A. V., Sviders'kij, A. T., Kostenjuk, O. O., Ruchins'kij, M. M., Djedov, O. P., Garkavenko, O. M. \& Martinjuk, I. Ju. (2013). Bases of the theory of the movement of the digging and condensing cars of the construction industry with the optimum parameters operated in time. Kyiv: MP Lesja.

4.Zaichenko, S., Shalenko, V., Shevchuk, N. \& Vapnichna, V. (2017). Development of a geomechanic complex for geotechnical monitoring contour mine groove. Eastern-European Journal of Enterprise Technologies, vol. 3/9 (87), 19-25. DOI: 10.155/1729. 4061.2017.102067.

5.Garnec,' V. M., Chovnjuk, Ju. V., Zajchenko, S. V., Shalenko, V. O. \& Prihod'ko, Ja. S. (2014). Theory and practice of creation of units of formation of concrete. Mining, construction, road and meliorative machines, No. $83,49-54$.

6. Garnec,' V. M., Zajchenko, S. V., Prihod'ko, Ja. S. \& Shalenko, V. O. (2012). Development of scientific and practical recommendations about creation of units of formation of concrete. Mining, construction, road and meliorative machines, No. 79, 46-52.

7. Zajchenko, S. V., Shevchuk, S. P., Garnec, 'V. M. (2012). Power analysis of process of roller consolidation. Power: Economy, technology, ecology, No. 1 (30), 77-83.

8. Zajchenko, S. V., Shevchuk, S. P., Garnec,' V. M. (2012). Three-dimensional modeling of process of roller consolidation of column fastening. Mining, construction, road and meliorative machines, No. 79, 40-45.

9. Prihod'ko, Ja., S. \& Garnec,' V. M. (2012). Interconsistency of operation of mechanisms at roller and extrusive formation of multihollow products. Branch mechanical engineering, construction, No. 1 (31), 305310.

10. Lovejkin, V. S. \& Pochka, K. I. (2007) Determination of optimum value of a corner of shift of cranks of roller forming installation with the recuperative drive. Automation of productions in mechanical engineering and instrument making, National University "Lviv Polyequipment", No. 41, 127-134.

11. Lovejkin, V. S. \& Pochka, K. I. (2008). Definition of loadings in elements of roller forming installations. Collection of scientific works of Ukrainian state academy of railway transport, No 88, 15-20.

12. Lovejkin, V. S. \& Pochka, K. I. (2007) Definition of loadings in elements of roller forming installation. Theory and practice of construction, No. 3, 19-23.
13. Lovejkin, V. S. \& Pochka, K. I. (2012). Research of dynamic loadings in elements of roller forming installations. Formation of Modern Science - 2012: Materials VIII of the intern. sci. and pract. conf. Section 18. Technical science. Formation of information technologies, Praha, 20-25.

14. Lovejkin, V. S. \& Pochka, K. I. (2015). Research of loadings in elements of roller forming installation with the balanced drive. Automation of productions in mechanical engineering and instrument making, National University "Lviv Polyequipment", No 49, 73-79

15. Lovejkin, V. S. \& Pochka, K. I. (2016). Analysis of dynamic equilibration of drives of cars of roller formation. MOTROL. Commission of Motorization and Energetics in Agriculture, Lublin-Rzeszow, vol. 18, No 3, 41-52.

16. Pat. 32838 UA, IPC B28B 13/00, Installation for formation of products from concrete mixes, Lovejkin, V. S., Jaroshenko, V. F., Pochka, K. I., Publ. 10.06.2008.

\section{Список літератури}

1.Ловейкін B. C. Динамічний аналіз роликової формовочної установки з рекупераційним приводом. Динаміка, міиність $i$ надійність с.-2 машин: Пр. I міжнар. наук.-техн.конф. (DSR AM-I). (Тернопіль, 4-7 жовт. 2004). Тернопіль, 2004. С. 507-514.

2.Ловейкін $B . \quad C ., \quad$ Почка $K . \quad$ I. Результати експериментальних досліджень режимів руху роликової формувальної установки з рекупераційним приводом. Вісн. Харк. нац. ун-ту сільськ. госп-ва ім. П. Василенка. 2007. Т 1. № 59. С. 465-474.

3.Назаренко I. І., Смірнов В. М., Пелевін Л. С., Фомін А. В., Свідерський А. Т., Костенюк О. О., Ручинський М. М., Дєдов О. П., Гаркавенко О. М., Мартинюк I. Ю. Основи теорії руху землерийних і ущільнювальних машин будіндустрії з керованими у часі оптимальними параметрами. К.: МП Леся, 2013. $188 \mathrm{c}$.

4.Zaichenko S., Shalenko V., Shevchuk N., Vapnichna $V$. Development of a geomechanic complex for geotechnical monitoring contour mine groove. Eastern-European J. Enterprise Technologies. 2017. Vol. 3/9 (87). P. 19-25. DOI: 10.155/1729-4061.2017.102067.

5.Гарнеиь В. М., Човнюк Ю. В., Зайченко С. В., Шаленко В. О., Приходько Я. С. Теорія і практика створення бетоноформувальних агрегатів (БФА). Гірн., буд., дор. та меліор. машини. 2014. Вип. 83. C. $49-54$

6. Гарнець В. М., Зайченко С. В., Приходько Я. С., Шаленко $B . \quad O$. Розробка науково-практичних рекомендацій по створенню бетоноформуючих агрегатів (БФА). Гірн., буд., дор. та меліор машини. 2012. Вип. 79. С. 46-52.

7. Зайченко С. В., Шевчук С. П., Гарнеиьь В. М. Енергетичний аналіз процесу роликового ущільнення. Енергетика: Економіка, технологія, екологія. 2012. № 1 (30). C. 77-83.

8. Зайченко С. В., Шевчук С. П., Гарнеиьь В. М. Тривимірне моделювання процесу роликового ущільнення стовбурного кріплення. Гірн., буд., дор. та меліор. машини. 2012. Вип. 79. С. 40-45. 
9. Приходько Я. С., Гарнець В. М. Взаємоузгодженість роботи механізмів при роликоекструзійному формуванні багатопустотних виробів. Галузеве машинобуд., буд-во. 2012. № 1 (31). С. 305310.

10. Ловейкін $B . \quad$ C., Почка $K . \quad$ I. Визначення оптимального значення кута зміщення кривошипів роликової формувальної установки з рекупераційним приводом. Автоматизачія вироб. процесів у машинобуд. та приладобуд. НУ «Львівська політехніка». 2007. № 41. С. 127-134.

11. Ловейкін $B . \quad C$., Почка $K$. $\quad$ I. Визначення навантажень в елементах роликових формувальних установок. 3б. наук. пр. Укр. акад. залізнич. трансп. Харків: УкрДАЗТ, 2008. Вип. 88. С. 15-20.

12. Ловейкін B. C., Почка $K$. I. Визначення навантажень в елементах роликової формувальної установки. Теорія і практика буд-ва. 2007. № 3. С. 19 23.

13. Ловейкін B. C., Почка K. I. Дослідження динамічних навантажень в елементах роликових формувальних установок. Vznik moderni vedecke 2012. Materialy VIII mezinarodni vedecko-prakticka conference- Dil. 18. Technicke vedy. Moderni informacni technologie: Praha. Publishing House "Education and Science"s.r.o. - P. 20-25.

14. Ловейкін B. C., Почка K. I. Дослідження навантажень в елементах роликової формувальної установки 3 врівноваженим приводом. Автоматизаиія виробн. проиесів у машинобуд. та приладобуд. НУ «Львівська політехніка», 2015. Вип. 49. С. 73-79.

15. Ловейкин $\quad B . \quad C$. , Почка $K . \quad$ И. Анализ динамического уравновешивания приводов машин роликового формования. MOTROL. Commission Motorization and Energetics in Agriculture. LublinRzeszow. 2016. Vol. 18. No 3. P. 41-52.

16. Ловейкін В. С., Ярошенко В. Ф., Почка К. I. Патент України на корисну модель № 32838 . Установка для формування виробів 3 бетонних сумішей - № u 20041108955 заявл. 02.11.2004; опубл. 10.06.2008, Бюл. № 11.

\section{ВИКОРИСТАННЯ МОДЕЛІ СТЕРЖНЯ ЗМІННОГО ПЕРЕРІЗУ В АНАЛІЗІ КОЛИВАНЬ ТЕЛЕСКОПІЧНИХ СТРІЛОВИХ СИСТЕМ АВТОКРАНІВ \\ I. М. Сівак, Ю. В. Човнюк}

Анотація. Обгрунтовано

дискретноконтинуальна модель стержня змінного перерізу для аналізу коливань телескопічних стрілових систем автокранів.

В якості методів розв'язання основних рівнянь (для згинальних типу коливань) використані методи Рітца і Буднова-Гальоркіна з застосуванням формули Релея для обчислення власної частоти коливань розглянутої системи 3 використанням моделі 3 зосередженими параметрами (тобто дискретні моделі) 3 урахуванням розподілених властивостей досліджуваних систем.

Використані підходи, для всебічного аналізу континуальных (розподілених) властивостей телескопічних стрілових систем автокранів i здійснено аналіз різновидів коливань (поздовжніх, крутильних i згинальних) телескопічних стрілових систем автокранів з урахуванням обставини розподілу маси вздовж стріли (стрижня) 3 перемінним перетином стрижня по його довжині.

Викладені наближені способи аналізу i вдосконалення методів розрахунку різних видів коливань, які виникають у стрижнях змінного перерізу, в рамках розгляду телескопічних стрілових систем автокранів як мають дискретно-континуальні властивості.

Складені рівняння за методом БубноваГальоркіна в задачі про поздовжні або крутильні коливання телескопічних стрілових систем автокранів.

Ключові слова: модель, стрижень, змінне перетин, аналіз, коливання, телескопічна стрілова система, автокрани.

\section{ИСПОЛЬЗОВАНИЕ МОДЕЛИ СТЕРЖНЯ ПЕРЕМЕННОГО СЕЧЕНИЯ В АНАЛИЗЕ КОЛЕБАНИЙ ТЕЛЕСКОПИЧЕСКИХ СТРЕЛОВЫХ СИСТЕМ АВТОКРАНОВ \\ И. Н. Сивак, Ю. В. Човнюк}

Аннотация. Обоснована дискретноконтинуальная модель стержня переменного сечения для анализа колебаний телескопических стреловых систем автокранов.

В качестве методов решения основных уравнений (для изгибных типа колебаний) использованы методы Ритца и Буднова-Галеркина с применением формулы Рэлея для вычисления собственной частоты колебаний рассматриваемой системы с использованием модели с сосредоточенными параметрами (тоесть дискретные модели) и учетом распределенных свойств исследуемых систем.

Использованы подходы, для всестороннего анализа континуальных (распределенных) свойств телескопических стреловых систем автокранов и осуществлен анализ разновидностей колебаний (продольных, крутильных и изгибных) телескопических стреловых систем автокранов с учетом обстоятельства распределения массы вдоль стрелы (стержня) с переменным сечением стержня по его длине.

Изложенные приближенные способы анализа и совершенствования методов расчета различных видов колебаний, которые возникают в стержнях переменного сечения, в рамках рассмотрения телескопических стреловых систем автокранов как имеющих дискретно-континуальные свойства.

Составленные уравнения по методу БубноваГалеркина в задачах о продольные или крутящие колебания телескопических стреловых систем автокранов.

Ключевые слова: модель, стержень, переменное сечение, анализ, колебания, телескопическая стреловая система, автокраны.

I. M. Sivak ORCID 0000-0002-6297-587X Yu. V. Chovnyuk ORCID 0000-0003-1889-0876. 